\title{
Penerapan Model Pembelajaran Berbasis Masalah untuk Meningkatkan Keterampilan Proses Sains Dan Hasil Belajar Fisika Materi Pokok Optika Geometri dan Alat Optik pada Peserta Didik Kelas XI MIA, SMA Negeri 1 Raha
}

\author{
Riyan Iskawati Rachmad ${ }^{1)}$, , La Sahara ${ }^{2)}$, Luh Sukariasih ${ }^{3)}$ \\ 1)*Mahasiswa Jurusan Pendidikan Fisika Fakultas Keguruan dan Ilmu Pendidikan UHO \\ ${ }^{2), 3)}$ Dosen Jurusan Pendidikan Fisika Fakultas Keguruan dan Ilmu Pendidikan UHO \\ *Korespondensi Email: riyaniskawati@gmail.com
}

\begin{abstract}
Abstrak: Penelitian ini bertujuan untuk: 1) menganalisis peningkatan keterampilan proses sains peserta didik kelas XI MIA2 SMA Negeri 1 Raha setelah penerapan model pembelajaraan berbasis masalah; 2) menganalisis peningkatan hasil belajar fisika peserta didik kelas XI MIA2 SMA Negeri 1 Raha setelah penerapan model pembelajaraan berbasis masalah; dan 3) menganalisis ketuntasan hasil belajar fisika peserta didik kelas XI MIA2 SMA Negeri 1 Raha setelah penerapan model pembelajaraan berbasis masalah. Subjek dalam penelitian ini adalah seluruh peserta didik kelas XI MIA2 SMA Negeri 1 Raha tahun ajaran 2018/2019. Data yang telah diperoleh pada penelitian ini adalah data mengenai keterampilan proses sains peserta didik yang diperoleh dari lembar observasi dan hasil belajar peserta didik yang diperoleh dari tes hasil belajar. Analisis data dilakukan secara statistik deskriptif. Dari hasil analisis data diperoleh kesimpulan bahwa: 1) keterampilan proses sains peserta didik setelah penerapan model pembelajaran berbasis masalah pada siklus I diperoleh nilai rata-rata sebesar 2,6 dengan kategori cukup dan pada siklus II diperoleh nilai rata-rata sebesar 3,2 dengan kategori baik dengan besar peningkatan sebesar 0,$6 ; 2$ ) hasil belajar Fisika peserta didik kelas XI MIA2 SMA Negeri 1 Raha setelah penerapan model pembelajaran berbasis masalah pada siklus I diperoleh nilai rata-rata 78,7 dengan standar deviasi sebesar 9,7 dan pada siklus II diperoleh nilai rata-rata 82,9 dengan standar deviasi sebesar 9,2; dan 3) ketuntasan hasil belajar Fisika peserta didik kelas XI MIA2 SMA Negeri 1 Raha pada siklus I diperoleh sebesar $64,3 \%$ dan pada siklus II sebesar $85,7 \%$ dengan peningkatan ketuntasan hasil belajar sebesar 21,4\%.
\end{abstract}

Kata Kunci: Model Pembelajaran Berbasis Masalah; Keterampilan Proses Sains; dan Hasil Belajar Peserta Didik.

Abstract: This study aims 1) to analyze the improvement of science process skills in class XI MIA 2 students of SMA Negeri 1 Raha after applying the problem based learning model; 2) to analyze the improvement in physics learning outcomes of students in class XI MIA 2 SMA Negeri 1 Raha after applying the problem based learning model; and 3) to analyze the completeness of physics learning outcomes for students of class XI MIA 2 in SMA Negeri 1 Raha after applying the problem based learning model. Subjects in this study were all students of class XI MIA 2 SMA Negeri 1 Raha in the 2018/2019 school year. The data that has been obtained in this study is data about students' science process skills obtained from observation sheets and student learning outcomes obtained from learning outcomes tests. Data analysis was performed statistically descriptive. From the results of data analysis, it was concluded that : 1) students' science process skills after the application of problem-based learning models in the first cycle obtained an average value of 2.6 with enough categories and in the second cycle an average value of 3.2 with good categories with a large increase of 0, 6; 2) physics learning outcomes of students in class XI MIA 2 SMA Negeri 1 Raha after the application of the problem-based learning model in the first cycle obtained an average of 78.7 with a standard deviation of 9.7 and in thr second cycle an average of 82.9 was obtained with standard deviation of 9.2; and 3) completeness of physics learning outcomes of students in class XI MIA 2 SMA Negeri 1 Raha in the first cycle obtained by $64.3 \%$ and in the second cycle amounted to 85.7 with an increase in mastery learning outcomes by $21.4 \%$.

Keywords: Problem Based Learning Model; Science Process Skills; and Learning Outcomes of Students.

\section{PENDAHULUAN}

Pendidikan memiliki peran yang sangat penting dalam meningkatkan kualitas sumber daya manusia dan keberhasilan pembangunan nasional. Salah satu kunci keberhasilan pendidikan adalah keberhasilan guru dalam menyajikan materi pelajaran yang dapat memfasilitasi peserta didik untuk mencapai kompetensi yang diharapkan. Hal ini dapat berkaitan dengan perolehan nilai hasil belajar peserta didik yang baik. Johari (2014), dalam penelitiannya mengungkapkan bahwa nilai hasil belajar peserta didik dapat ditingkatkan apabila proses pembelajaran berlangsung 
secara efektif dan efisien serta ditunjang dengan tersediannya sarana dan prasarana pendukung, kecakapan guru dalam pengelolaan kelas dan penguasaan materi yang memadai serta melibatkan peserta didik aktif dan memberikan kesempatan peserta didik secara nyata bertindak sebagai seorang ilmuwan sehingga dapat meningkatkan kreativitas dan keterampilan peserta didik.

Fisika merupakan salah satu mata pelajaran yang membutuhkan pemahaman dan pengembangan konsep kuat pada materi pelajarannya, seperti pada materi alatalat optik. Dalam materi ini peserta didik tidak hanya dituntut untuk mengetahui alat-alat optik tersebut namun juga perlu mengetahui proses dan faktor-faktor yang mengakibatkan terbentuknya alat-alat optik tersebut. Pemahaman konsep menuntut peserta didik untuk tidak sekedar menghafal materi dan rumusrumusnya namun harus mengetahui, menalar dan memahami konsep dari materi tersebut.

Berdasarkan hasil wawancara pada guru mata pelajaran fisika dan beberapa peserta didik di SMA Negeri 1 Raha pada tanggal 14 Desember 2018 diperoleh beberapa informasi sebagai berikut: pertama, nilai ulangan harian pada aspek pengetahuan dan keterampilan peserta didik kelas XI pada tahun ajaran 2017/2018 yang tersebar dalam delapan kelas paralel yang paling rendah adalah kelas XI MIA2 pada materi alat-alat optik sebagaimana terlampir.

Persentase nilai rata-rata ulangan harian kelas XI MIA2 lebih rendah dibandingkan kelas lainnya dimana persentasenya hanya $68 \%$ yang tuntas dan $32 \%$ yang belum tuntas atau dengan kata lain dari jumlah peserta didik 28 orang hanya terdapat 16 orang yang tuntas (nilai ulangan harian KKM 75) dan selebihnya tidak tuntas karena berada dibawah KKM.

Kedua, berdasarkan hasil pengamatan proses pembelajaran di dalam kelas dan wawancara dengan beberapa peserta didik, mereka mengungkapkan bahwa model pembelajaran yang digunakan guru tidak menarik minat peserta didik untuk belajar. Hal ini disebabkan karena sekolah tersebut belum menerapkan model-model pembelajaran yang dituntut dalam kurikulum 2013 (model pembelajaran Inkuiri, Discovery Learning, Problem Based Learning dan Project Besed Learning) meskipun sekolah tersebut telah menerapkan kurikum 2013.

Ketiga, pada materi pelajaran alat-alat optik ini peserta didik belum dapat memahami secara konsep pembentukan bayangan dan sifat-sifat bayangan yang terbentuk pada cermin, lensa, dan beberapa alat optik. Peserta didik yang bisa menghafal teori dari materi tersebut.

Berdasarkan permasalahan yang telah dijelaskan di atas, diyakini bahwa hal-hal yang mempengaruhi proses belajar mengajar di dalam kelas kurang kondusif yang menyebabkan tingkat pengetahuan dan keterampilan peserta didik yang kurang baik adalah faktor pengajar, faktor peserta didik dan juga faktor dari materi ajarnya. Faktor guru adalah faktor utama dalam keberhasilan kegiatan belajar mengajar. Dalam hal ini pengajar memegang peran penting dalam kegiatan belajar mengajar. Oleh karena itu, guru tidak sekedar menyampaikan ilmu pengetahuan kepada peserta didik, tetapi guru juga dituntut untuk memainkan berbagai peran yang bertujuan mengembangkan potensi peserta didik. Metode, model atau strategi pembelajaran yang digunakan sangat mempengaruhi suasana belajar mengajar di dalam kelas.

Salah satu alternatif tindakan dalam upaya memperbaiki proses pembelajaran fisika yaitu dengan menerapkan model pembelajaran berbasis masalah. Dalam penelitian ini model pembelajaran berbasis masalah dipilih dengan alasan lebih mendorong peserta didik untuk lebih aktif sehingga proses belajar mengajar lebih menyenangkan, kritis dan mandiri dalam memperoleh pengetahuannya sendiri yang menjadikan mereka lebih memahami konsep materi tersebut. Sangat cocok bila digunakan pada keterampilan proses sains, karena kegiatan dalam pembelajaran berbasis masalah dapat memberikan pengalaman dan pengetahuan peserta didik dalam merumuskan masalah dan menemukan solusi atau memecahkan masalah dari masalah nyata yang diberikan oleh pengajar sehingga peserta didik dapat memperdalam pemahaman materi dan menumbuhkan kemampuan berpikir seperti yang terdapat dalam keterampilan proses sains.

Carin (1992), menyampaikan beberapa alasan tentang pentingnya keterampilan proses. Pertama, dalam praktiknya sains tidak hanya sekedar mengetahui materi tentang sains saja tetapi terkait pula dengan memahami bagaimana cara untuk mengumpulkan fakta dan menghubungkan fakta-fakta untuk membuat suatu penafsiran atau kesimpulan. Kedua, keterampilan proses merupakan keterampilan belajar sepanjang hayat yang dapat digunakan bukan saja untuk mempelajari ilmu tetapi juga dapat digunakan dalam kehidupan sehari-hari.

Nensy Rerung, dkk (2017), membuktikan bahwa adanya peningkatan hasil belajar peserta didik kelas XI MIA6 SMA Negeri 1 Manokwari menggunakan model pembelajaran pembelajaran berbasis masalah pada materi usaha dan energi. Ni Nyoman Suardani (2014), dalam penelitiannya membuktikan bahwa dalam pencapaian keterampilan proses sains model pembelajaran berbasis masalah lebih baik dibandingkan dengan model pembelajaran langsung.

Berdasarkan uraian sebelumnya, maka dipandang perlu melakukan penelitian tentang peningkatan 
keterampilan proses sains dan hasil belajar peserta didik terhadap penerapan model pembelajaran berbasis masalah pada materi pokok optika geometri dan alat optik. Karena itu dilakukan penelitian dengan judul Penerapan Model Pembelajaran Berbasis Masalah untuk Meningkatkan Keterampilan Proses Sains dan Hasil Belajar Fisika Materi Pokok Optika Geometri dan Alat Optik pada Peserta Didik kelas XI MIA2 SMA Negeri 1 Raha.

\section{METODE}

Jenis penelitian ini adalah penelitian tindakan kelas (classroom action research) dan dilaksanakan pada tanggal 25 Maret sampai 21 April 2019 semester genap
Tahun Ajaran 2018/2109 di SMA Negeri 1 Raha, Kota Raha Kabupaten Muna, Sulawesi Tenggara.

Subjek penelitian ini adalah peserta didik kelas XI MIA2 SMA Negeri 1 Raha semester genap yang terdaftar pada tahun ajaran 2018/2019 dengan jumlah peserta didik 28 orang yang terdiri atas 18 orang lakilaki dan 10 orang perempuan. Teknik analisis data yang digunakan dalam penelitian ini berupa analisis deskriptif yang dimaksudkan untuk memberikan gambaran distribusi keterampilan proses sains dan hasil belajar peserta didik ranah kognitif yang diajar dengan menggunakan model pembelajaran berbasis masalah. Penelitian tindakan kelas ini merupakan proses pengkajian melalui sistem bersiklus seperti pada gambar berikut.

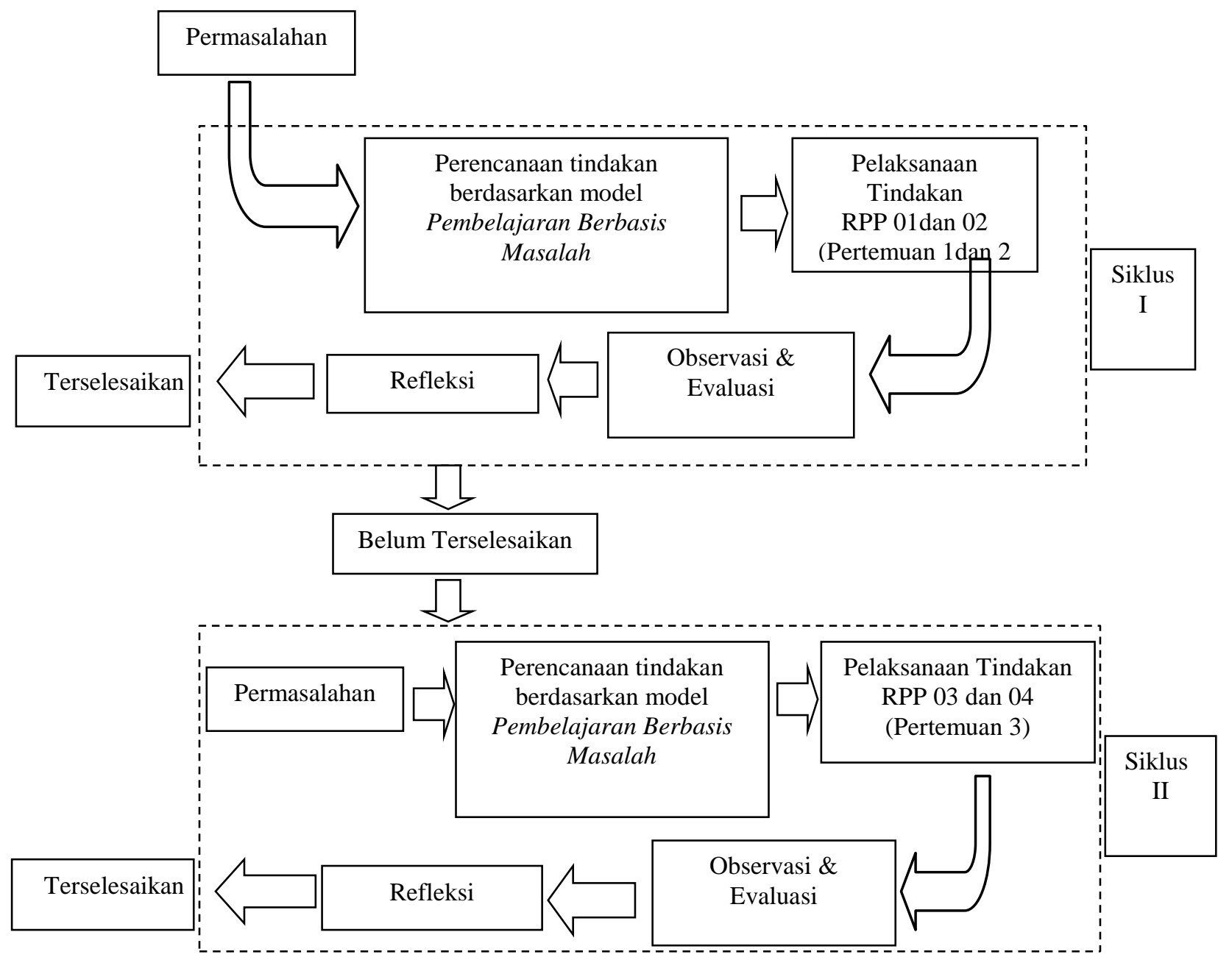

Gambar 1 Rancangan dan Desain Penelitian Tindakan Kelas dengan Model Pembelajaran Berbasis Masalah 


\section{HASIL PENELITIAN}

Tabel 1 Skor Rata-rata Keterampilan Proses Sains Peserta Didik pada Siklus I dan Siklus II

\section{Indikator}

Skor Rata-rata Keterampilan Proses Sains

\section{Siklus I}

\section{Siklus II}

\begin{tabular}{lcccc} 
& Pert. 1 & Pert. 2 & Pert. 3 & Pert. 4 \\
\hline Observasi (Mengamati) & 2,4 & 3,2 & 3,2 & 3,4 \\
\hline Merumuskan Masalah & 2,4 & 2,8 & 3,0 & 3,2 \\
\hline Merencanakan Percobaan & 2,4 & 3,0 & 3,4 & 3,4 \\
\hline Menginterpretasikan Data & 2,8 & 3,0 & 3,4 & 3,4 \\
\hline Menerapkan Konsep dan Prinsip & 2,0 & 2,8 & 3,0 & 3,0 \\
\hline Menyimpulkan & 2,0 & 3,0 & 3,2 & 3,6 \\
\hline Mengkomunikasikan & 2,2 & 2,6 & 2,8 & 2,8 \\
\hline Rata-rata & 2,3 & 2,9 & 3,1 & 3,3 \\
\hline Kategori & Cukup & Cukup & Baik & Baik
\end{tabular}

Tabel 2 Nilai Hasil Belajar Peserta Didik pada Siklus I dan Siklus II

\begin{tabular}{|c|c|c|c|c|c|}
\hline \multirow{2}{*}{ No. } & \multirow{2}{*}{ Inisial PD } & \multicolumn{2}{|c|}{ Siklus I } & \multicolumn{2}{|c|}{ Siklus II } \\
\hline & & Nilai & Ketuntasan & Nilai & Ketuntasan \\
\hline 1 & FRL & 90,6 & $\mathrm{~T}$ & 89,4 & $\mathrm{~T}$ \\
\hline 2 & $\mathrm{~A}$ & 89,4 & $\mathrm{~T}$ & 92,9 & $\mathrm{~T}$ \\
\hline 3 & SAA & 88,2 & $\mathrm{~T}$ & 94,1 & $\mathrm{~T}$ \\
\hline 4 & $\mathrm{YN}$ & 87,1 & $\mathrm{~T}$ & 89,4 & $\mathrm{~T}$ \\
\hline 5 & WR & 85,9 & $\mathrm{~T}$ & 87,1 & $\mathrm{~T}$ \\
\hline 6 & MNI & 84,7 & $\mathrm{~T}$ & 82,4 & $\mathrm{~T}$ \\
\hline 7 & FRAW & 83,5 & $\mathrm{~T}$ & 91,8 & $\mathrm{~T}$ \\
\hline 8 & $\mathrm{H}$ & 82,4 & $\mathrm{~T}$ & 84,7 & $\mathrm{~T}$ \\
\hline 9 & MK & 82,4 & $\mathrm{~T}$ & 84,7 & $\mathrm{~T}$ \\
\hline 10 & RAS & 82,4 & $\mathrm{~T}$ & 83,5 & $\mathrm{~T}$ \\
\hline 11 & RAZ & 82,4 & $\mathrm{~T}$ & 85,9 & $\mathrm{~T}$ \\
\hline 12 & VAA & 82,4 & $\mathrm{~T}$ & 83,5 & $\mathrm{~T}$ \\
\hline 13 & WTM & 82,4 & $\mathrm{~T}$ & 89,4 & $\mathrm{~T}$ \\
\hline 14 & YAS & 81,2 & $\mathrm{~T}$ & 81,2 & $\mathrm{~T}$ \\
\hline 15 & LSM & 78,8 & $\mathrm{~T}$ & 74,1 & BT \\
\hline 16 & FSA & 77,6 & $\mathrm{~T}$ & 81,2 & $\mathrm{~T}$ \\
\hline 17 & MI & 77,6 & $\mathrm{~T}$ & 81,2 & $\mathrm{~T}$ \\
\hline 18 & RFJ & 77,6 & $\mathrm{~T}$ & 80,0 & $\mathrm{~T}$ \\
\hline 19 & $\mathrm{AF}$ & 74,1 & $\mathrm{BT}$ & 81,2 & $\mathrm{~T}$ \\
\hline 20 & $\mathrm{~F}$ & 74,1 & BT & 80,0 & $\mathrm{~T}$ \\
\hline 21 & LES & 72,9 & BT & 78,8 & $\mathrm{~T}$ \\
\hline 22 & NAA & 72,9 & $\mathrm{BT}$ & 70,6 & $\mathrm{BT}$ \\
\hline 23 & $\mathrm{H}$ & 71,8 & BT & 80,0 & $\mathrm{~T}$ \\
\hline 24 & LRH & 71,8 & BT & 83,5 & $\mathrm{~T}$ \\
\hline 25 & MDR & 71,8 & BT & 80,0 & $\mathrm{~T}$ \\
\hline 26 & $\mathrm{FF}$ & 69,4 & BT & 82,4 & $\mathrm{~T}$ \\
\hline 27 & LIA & 69,4 & $\mathrm{BT}$ & 74,1 & $\mathrm{BT}$ \\
\hline 28 & $\mathrm{MZ}$ & 60,0 & BT & 72,9 & $\mathrm{BT}$ \\
\hline & Rata-rata & & & & \\
\hline
\end{tabular}




\begin{tabular}{ccc}
\hline Standar Deviasi & 9,7 & 9,2 \\
\hline Nilai maksimum & 90,6 & 94,1 \\
\hline Nilai minimum & 60,0 & 70,6 \\
\hline Persentase tuntas & $64,3 \%$ & $85,7 \%$ \\
\hline $\begin{array}{c}\text { Persentase belum } \\
\text { tuntas }\end{array}$ & $35,7 \%$ & $14,3 \%$ \\
\hline
\end{tabular}

\section{Pembahasan}

Pelaksanaan penelitian tindakan kelas ini dilaksanakan di SMA Negeri 1 Raha khususnya pada siswa kelas XI MIA2 yang terdiri dari 28 orang peserta didik yang dipilih berdasarkan nilai hasil ulangan harian yang paling rendah. Model pembelajaran yang digunakan adalah model pembelajaran berbasis masalah. Langkah-langkah dari model pembelajaran berbasis masalah meliputi kegiatan guru seperti observasi (mengamati), merumuskan masalah, merencanakan percobaan, menafsirkan pengamatan, membuat kesimpulan dan mengkomunikasikan. Tindakan yang dilakukan pada setiap pertemuan berdasarkan langkah-langkah tersebut digunakan sebagai stimulus terhadap peningkatan keterampilan, dan hasil belajar peserta didik.

Materi yang diajarkan dalam penelitian tindakan kelas ini adalah optik geometri dan alat optik, dengan tiga sub materi pokok yaitu pemantulan cahaya, pembiasan cahaya dan alat-alat optik. Selain itu data yang dikumpulkan dalam penelitian ini adalah data keterampilan proses sains, hasil belajar peserta didik dan data aktivitas guru yang dinilai pada setiap pertemuan berdasarkan kriteria penilaian yang telah ditentukan.

Berdasarkan hasil analisis data yang telah diuraikan sebelumnya terkait jawaban permasalahan mengenai keterampilan proses sains, hasil belajar serta ketuntasan hasil belajar peserta didik kelas XI MIA2 SMA Negeri 1 Raha terhadap penerapan model pembelajaran berbasis masalah pada setiap pertemuan disetiap siklusnya mengalami peningkatan. Peningkatan tersebut dapat dilihat pada Tabel di atas yang masing-masing menjelaskan serta memberikan gambaran mengenai data keterampilan proses sains peserta didik, tes hasil belajar peserta didik dan aktivitas guru yang cenderung mengalami peningkatan. Berikut uraian penjelasan terkait gambaran peningkatan keterampilan proses sains, tes hasil belajar peserta didik dan aktivitas guru.

\section{Siklus I}

Pelaksanaan tindakan pada siklus pertama dilakukan sebanyak 2 kali pertemuan. Pada setiap pertemuan dilakukan selama 2 jam pelajaran ( 2 x 45 menit). Pertemuan petama pada siklus ini dilaksanakan pada hari Senin tanggal 25 Maret 2019 dan berakhir pada hari Kamis tanggal 28 Maret 2019. Sub pokok materi yang dipelajari oleh peserta didik pada pertemuan pertama dan kedua adalah pemantulan cahaya dan pembiasan cahaya yang dilaksanakan berdasarkan rancangan kegiatan pada RPP (01) dan RPP (02).

\section{Keterampilan Proses Sains Peserta Didik}

Berdasarkan hasil analisis deskriptif terhadap keterampilan proses sains peserta didik pada siklus I menunjukkan perolehan skor rata-rata keterampilan inkuiri dari semua kelompok peserta didik sebesar 2,3 dengan kategori cukup. Aspek keterampilan proses sains yang masuk dalam skor terendah diantaranya aspek menerapkan konsep dan prinsip yang dapat dilihat pada saat mereka mengerjakan soal yang ada pada LKPD, aspek menyimpulkan pada saat mereka membuat kesimpulan berdasarkan hasil dan analis data yang mereka lakukan serta aspek mengkomunikasikan yang dapat dilihat pada saat mereka membuat laporan hasil pengamatan. Mereka masih terkesan bingung dalam menyusun laporan hasil pengamatan. Solusi yang diupayakan yaitu guru harus lebih berusaha dalam membimbing peserta didik saat proses pembelajaran, mendekatkan diri kepada peserta didik untuk selalu bertukar informasi dan menanyakan masalah apa yang menjadi kendala pada saat pembelajaran berlangsung.

\section{Aktivitas Guru}

Berdasarkan hasil analisis deskriptif terhadap aktivitas guru pada siklus I diperoleh skor rata-rata sebesar 2,8 dan 3,1 dengan kategori baik. Meskipun sudah berada dalam kategori baik namun ada beberapa aspek aktivitas guru yang perlu ditingkatkan seperti waktu sesuai alokasi, dimana pada pembelajaran disiklus I alokasi waktu pembelajaran yang digunakan guru masih belum sesuai dengan alokasi waktu yang seharusnya. Kurang maksimalnya aktivitas guru disebabkan guru belum sepenuhnya melaksanakan kegiatan pembelajaran sesuai dengan langkah-langkah model pembelajaran berbasis masalah sehingga masih terdapat beberapa kekurangan dalam pelaksanaannya.

\section{Hasil Belajar Peserta Didik}

Keterampilan proses sains peserta didik dan aktivitas guru pada proses pembelajaran disiklus I juga 
berdampak pada hasil belajar yang diperoleh peserta didik. Berdasarkan hasil analisis nilai rata-rata peserta didik dapat dilihat bahwa dari 28 orang peserta didik yang mengikuti tes siklus tersebut terdapat 10 orang peserta didik yang memiliki nilai hasil belajar yang berada pada kategori minimal atau nilai tes siklusnya berada dibawah KKM yang telah ditentukan oleh sekolah yaitu $\geq 75$. Selebihnya berada pada kategori optimal sebanyak 18 peserta didik. Rendahnya nilai rata-rata peserta didik tentu saja akan mempengaruhi persentase kelulusan peserta didik. Persentase ketuntasan belajar yang diperoleh pada siklus I belum mencapai target penelitian yaitu belum mencapai ketuntasan belajar secara klasikal $75 \%$ seperti yang terlihat pada Tabel 4.3. Jumlah persentase ketuntasan belajar pada siklus I yang diperoleh secara klasikal yaitu 64,3\% dari 28 jumlah peserta didik.

Selain itu, standar deviasi yang diperoleh juga cukup tinggi menunjukkan nilai hasil belajar peserta didik masih rendah. Berdasarkan hasil analisis deskriptif terhadap banyaknya persentase pesera didik yang belum mencapai standar KKM menunjukan adanya beberapa kekurangan dalam proses pembelejaran siklus I, diantaranya peserta didik yang belum terbiasa dengan model pembelajaran berbasis masalah, kurangnya pengetahuan peserta didik dalam menggunakan operasi matematika yang benar ketika mengerjakan soal tes hasil belajar serta guru yang belum optimal membimbing dan mengarahkan peserta didik dalam proses pembelajaran.

\section{Refleksi}

Dari masalah tersebut peneliti dan guru mata pelajaran melakukan analisis dan refleksi terhadap faktor-faktor yang menyebabkan kurangnya keterampilan proses sains peserta didik, rendahnya nilai hasil belajar peserta didik serta beberapa aspek aktivitas guru dalam proses pembelajaran, antara lain sebagai berikut.

a) Peserta didik belum sepenuhnya memahami cara pengumpulan data yang benar dan tepat.

b) Peserta didik kurang memahami cara membuat kesimpulan dari hasil percobaan yang diperoleh.

c) Guru masih kurang dalam membimbing dan mengarahkan peserta didik ketika melaksnakan percobaan.

d) Guru masih kurang dalam mengarahkan peserta didik untuk mengumpulkan data pengamatan melalui percobaan.

e) Guru masih kurang dalam mengarahkan peserta didik untuk membuat kesimpulan berdasarkan hasil percobaan.

f) Waktu pembelajaran masih belum sesuai alokasi.
Selanjutnya peneliti bersama guru juga menentukan langkah-langkah perbaikan untuk siklus II, antara lain sebagai berikut.

a) Guru perlu memperhatikan dan melakukan kegiatan awal pada saat proses pembelajaran dengan memberikan motivasi kepada peserta didik berupa pertanyaan serta tidak terburu-buru meminta jawaban kepada peserta didik terkait pertanyaan yang diberikan atau memberikan sedikit waktu kepada peserta didik untuk memikirkan jawaban dari pertanyaan tersebut.

b) Guru harus menjelaskan lebih detail lagi dan memberi contoh tentang cara menafsirkan pengamatan, merumuskan kesimpulan dan menyusun laporan hasil pengamatan yang benar.

c) Guru harus memberikan contoh soal beserta penyelesaiannya termasuk operasi matematika yang terdapat di dalamnya.

d) Guru perlu memahami setiap langkah pembelajaran dan melaksanakan seluruh kegiatan pembelajaran secara optimal dengan demikian waktu yang dibutuhkan pada setiap kegiatan akan menjadi lebih terarah dan tidak hanya terfokus pada satu kegiatan pembelajaran yang dapat menghabiskan waktu.

\section{Siklus II}

Siklus II dilaksanakan sesuai rencana yaitu dua kali pertemuan pada tanggal 15 April 2019 dan berakhir tanggal 18 April 2019. Pada siklus ini materi yang dipelajari adalah sub materi alat-alat optik.

\section{Keterampilan Proses Sains Peserta Didik}

Dari hasil analisis deskriptif pada siklus II menunjukkan adanya peningkatan keterampilan proses sains peserta didik dari siklus I. Aspek-aspek keterampilan proses sains yang pada siklus I berada pada kategori cukup mengalami peningkatan yang lebih baik seperti yang terlihat pada Tabel 4.2, dengan perolehan skor rata-rata keterampilan proses sains sebesar 3,3 dengan kategori baik. Peningkatan rata-rata keterampilan proses sains peserta didik menandakan bahwa kekurangan atau kelemahan-kelemahan yang terdapat pada siklus I dapat teratasi yang berdasarkan hasil refleksi dan perbaikan sehingga keterampilan proses sains peserta didik dapat meningkat dari sebelumnya.

\section{Aktivitas Guru}

Aktivitas guru dalam mengelola pembelajaran juga mengalami peningkatan dari siklus I. Aspek-aspek aktivitas guru yang sebelumnya pada siklus I berada pada kategori cukup mengalami peningkatan pada 
siklus II sehingga berada pada kategori baik dan sangat baik. Hal ini menunjukkan pengelolaan pembelajaran yang dilakukan oleh guru telah sesuai dengan langkahlangkah model pembelajaran berbasis masalah, dimana skor rata-rata yang diperoleh sebesar 3,5 dengan kategori sangat baik.

\section{Hasil Belajar}

Berdasarkan hasil analisis deskriptif terhadap hasil belajar peserta didik pada siklus II untuk sub materi alat-alat optik mengalami peningkatan dari siklus I sebelumnya, seperti yang terlihat pada Tabel 4.3. Berdasarkan data tersebut, jumlah peserta didik yang tuntas meningkat menjadi 24 orang dan sisanya yang belum tuntas yaitu 4 orang. Jika diperhatikan nilai yang diperoleh peserta didik berada pada kategori optimal serta tidak ada lagi peserta didik yang memperoleh nilai dengan kategori minimal ataupun kurang. Standar deviasi yang diperoleh pun lebih kecil dibandingkan dengan siklus I. Hal ini menunjukkan peningkatan persentase ketuntasan belajar peserta didik yang telah mencapai ketuntasan secara klasikal sebesar $85,7 \%$ dari jumlah peserta didik 28 orang, yang artinya telah mencapai bahkan melewati target penelitian sebesar 75\% ketuntasan secara klasikal.

Peningkatan keterampilan berbasis masalah peserta didik dan aktivitas guru serta hasil belajar peserta didik menunjukkan bahwa guru telah melakukan perbaikan berdasarkan analisis dan refleksi yang telah dilakukan sebelumnya. Penggunakan model pembelajaran berbasis masalah menjadikan peserta didik menjadi lebih antusias dan aktif didalam proses belajar mengajar.

Berdasarkan uraian di atas, dapat dikatakan bahwa penerapan model pembelajaran berbasis masalah di kelas XI MIA2 SMA Negeri 1 Raha dapat meningkatkan keterampilan proses sains dan hasil belajar peserta didik pada materi pokok optika geometri dan alat-alat optik.

\section{KESIMPULAN}

Keterampilan proses sains peserta didik kelas XI MIA2 SMA Negeri 1 Raha setelah penerapan model pembelajaran berbasis masalah pada materi pokok optika geometri dan alat optik mengalami peningkatan. Hal ini ditunjukkan dengan skor rata-rata aspek keterampilan proses sains peserta didik pada siklus I dan siklus II. Dimana pada siklus I diperoleh nilai ratarata sebesar 2,6 dengan kategori cukup dan pada siklus II diperoleh nilai rata-rata sebesar 3,2 dengan kategori baik dengan besar peningkatan sebesar 0,6. Hasil belajar peserta didik kelas XI MIA2 SMA Negeri 1 Raha setelah penerapan model pembelajaran berbasis masalah pada materi pokok optika geometri dan alat optik mengalami peningkatan. Hal ini ditunjukkan dengan peningkatan skor rata-rata hasil belajar peserta didik pada siklus I dan siklus II. Dimana pada siklus I diperoleh nilai rata-rata 78,7 dengan standar deviasi sebesar 9,7 dan pada siklus II diperoleh nilai rata-rata 82,9 dengan standar deviasi sebesar 9,2. Ketuntasan belajar Fisika peserta didik kelas XI MIA2 SMA Negeri 1 Raha setelah penerapan model pembelajaran berbasis masalah pada materi pokok optika geometri dan alat optik cenderung mengalami peningkatan, dimana persentase ketuntasan belajar pada siklus I diperoleh sebesar $64,3 \%$ dan pada siklus II sebesar $85,7 \%$ dengan peningkatan ketuntasan hasil belajar sebesar $21,4 \%$.

\section{DAFTAR PUSTAKA}

Amir, T. 2010. Inovatif Pendidikan Melalui Problem Based Learning Bagaimana Pendidikan Memberdayakan Pembelajaran di Era Pengetahuan. Jakarta: Kencana.

Arends, R. 1997. Classroom Introduction Management. New York: The Mc Graw-Hill Company.

Arikunto, S. 2009. Dasar-Dasar Evaluasi Pendidikan Edisi Revisi Cet.10. Jakarta: Bumi Aksara.

-----, 2018. Dasar-Dasar Evaluasi Pendidikan Edisi 2. Jakarta: Bumi Aksara.

Carin, A. 1993. Teaching Science Through Discovery. New York Macmilan Publishing Company.

Daryanto, 2014. Pendekatan Pembelajaran Saintifik Kurikulum 2013. Yogyakarta: Gava Media.

Hamalik, O. 2008. Kurikulum dan Pembelajaran. Jakarta: Bumi Aksara.

Hamiyah, N. 2014. Strategi Belajar Mengajar di kelas. Jakarta: Prestasi Pustakarya

Herayanti,.dkk. 2015. Model Pembelajaran Berbasis Masalah Berbantuan Simulasi Komputer untuk Meningkatkan Keterampilan Berpikir Kritis Calon Guru Fisika. Mataram: IKIP Mataram.

Kurniawati, A. 2015. Analisis Keterampilan Proses Sains Peserta Didik kelas XI Semester II MAN Tempel tahun ajaran 2012/2013 pada Pembelajaran Kimia dengan Model Learning Cycle 5E. Yogyakarta: Universitas Negeri Yogyakarta.

Nasution, S. 2006. Berbagai Pendekatan dalam Proses Belajar Mengajar. Jakarta: Bumi Aksara.

Nurhasanah. 2016. Penggunaan Tes Keterampilan Proses Sains Siswa dalam Pembelajaran Konsep kalor dengan Model Inkuiri Terbimbing. Jakarta: UIN Syarif Hidayatullah Jakarta.

Prabawati, R. 2014. Upaya Peningkatan Aktivitas dan Hasil Belajar Fisika Siswa melalui Penerapan Model Pembelajaran Berpikir Induktif pada 
Materi Kalor di kelas X.2 MAN 1 Model Kota Bengkulu. Bengkulu: Universitas Bengkulu.

Prayogi, S. 2015. Reviu Literatur tentang Keterampilan Proses Sains. Mataram: Universitas Mataram.

Prihantoro, A. 2017. Kerangka Landasan untuk Pembelajaran, Pengajaran, dan Asesmen. Yogyakarta: Pustaka Pelajar.

Purwanto, M Ngalim. 1992. Psikologi pendidikan. Bandung: PT. Remaja Rosdakarya.

Rerung, N. 2017. Penerapan Model Pembelajaran Problem Based Learning (PBL) untuk Meningkatkan Hasil Belajar Peserta Didik SMA pada Materi Usaha dan Energi. Monokwari: UNIPA.

Rustaman, 2003. Keterampilan Proses Sains (Online) (http:biopointtenten.blogspot. com/2010/08/keterampilan-proses-sainskps.html.

Sanjaya, 2008. Strategi Pembelajaran. Jakarta: Kencana.

Savery, J. R.,(2006). Overview of Problem Based Learning: Definitions and Distinction. The Interdiciplinary Journal of Problem-Based Learning.

http://www.tne.uconn.edu/Case/Method/Savery/2 006.Pdf.

Suardani, N. 2014. Pengaruh Model Pembelajaran Berbasis Masalah terhadap Kemampuan
Pemecahan Masalah dan Keterampilan Proses Sains. Singaraja: Universitas Pendidikan Ganesha. Vol. 4.

Sudjana. 2010. Metoda Statistika. Bandung: Tarsito.

Sudjana, N. 2007. Penilaian Hasil Proses Belajar Mengajar. Bandung: PT Remaja Rosdakarya.

Sugianto, 2001. Model - Model Pembelajaran Inovatif. Surakarta. Yuma Pustaka.

Suherman, E,dkk, 2008. Strategi Pembelajaran Matematika Kontenporer. JICA: UPI.

Suryani, A, dkk. 2015. Pengembangan Instrumen Tes untuk Mengukur Keterampilan Proses Sains Siswa SMP pada Materi Gerak. Bandung.

Trianto, 2001. Model - Model Pembelajaran Inovatif Berorientasi Konstruktivistik. Surakarta: UGM.

-------,2007. Model Pembelajaran Terpadu dalam Teori dan Praktek. Jakarta: Prestasi Pustaka.

------, 2011. Model Pembelajaran Terpadu. Jakarta: Bumi Aksara.

Undang - Undang Republik Indonesia Nomor 20 Tahun 2003. Sistem Pendidikan Nasional. Departemen Pendidikan Nasional Republik Indonesia. Jakarta.

Usman, dkk. 2001. Upaya Optimalisasi Kegiatan Belajar Mengajar. Bandung: PT Remaja Rosdakarya.

Widi, W. A, dkk. 2017. Metodologi Pembelajaran IPA. Jakarta: Bumi Aksara. 